Article

\title{
Assessment of the History and Cultural Inclusion of Public Art in Pakistan
}

\author{
Syed Asifullah Shah ${ }^{1, *}$, Ashfaq Ahmad Shah ${ }^{2}$ and Li Xianfeng ${ }^{1,}$ \\ 1 Department of Ornamental Horticulture and Landscape Architecture College of Horticulture, China \\ Agricultural University, Beijing, 100193, P.R. China asifshah@cau.edu.cn fineart@cau.edu.cn \\ 2 College of Humanities and Development studies, China Agricultural University, Beijing, 100193, P.R. \\ China shahaa@cau.edu.cn
}

* Correspondence: asifshah@cau.edu.cn; asif_aup@yahoo.com

\begin{abstract}
The significance of arts incorporated with culture inclusion makes the arts a matter of pressing interest. The arts are vital elements of a healthy society that benefits the nations even in difficult social and economic times. Based on the previous studies this research was conducted for the first time in Pakistan to explore the historical background of public art correlated with cultural and religious ethics. Though, Pakistan has a rich cultural history yet the role of modern public art is new and often used unintentionally. Our findings of different surveys conducted in Pakistan including oldest cities such as Lahore, Peshawar and newly developed, the capital city, Islamabad concluded that Public art has a rich cultural and historical background and the local community are enthusiastically connected to it. Different community groups prefer different types of public art in their surroundings depends on the city's profile, cultural background, and religious mindset of the local community. Overall, the sculptures and depiction of animated beings are not considering right and debatable among the Pakistani societies. On the other hand, the cultural and historical monuments are highly appreciated and welcomed by the local community of Pakistan. This study may create scope for future estimation and development of public art in Pakistan in association with Islamic laws and cultural norms of the local society.
\end{abstract}

Keywords: Public Art; Cultural identity; Islamic society; Art history; Pakistan.

\section{Introduction}

Public Art exists since long in various shapes in different societies, (Omar et al. 2016) that are being exposed to the emerging and submerging of different civilizations with the passage of time in association with the interactive phases of civilization clashes. Some of the art Pieces do available in some distinctive form with unique identities such as Egyptian pyramids, the Italian and the Mexican sculptures, the Chinses Paintings, etc. The recent trends of public art started from the U.S.A. which have played a leading role in modern Public Art during late 19th and earlier 20th century with initiating Art in Architecture (A-i-A) programs (Knight 2011) which further developed into percent for art programs (Weethalle 1993). The modern Public Art existing in the world as informal rules of thumb rather than acting in a codified standards irrespective of what it constitutes of (Hunting 2005). While talking with modifications, innovations, and rapidity in the pace of development among different societies, ethnic groups or to educate a broad range of audiences of Public art, a fixed definition is very difficult (Hein 1996; Selwood 1995; Hunting 2005). The word Public Art is an umbrella term which is used for different groups of artworks that specified a particular locality with a special purpose installed in a public sphere and intended for public use (Selwood 1995). Commonly, the term Public Art refers to the object's history and origin, location, public involvement and social purposes. However, the definition of Public Art is changing across the world due to technological evolution, economic development, cultural shift, and rapid urbanism 
(Hein 1996). Public art is often freely accessible to all the public at any point with no distinctive enclosure or boundaries (Selwood 1995). In a common opinion, Public art is often understood as sculptures and monuments. Generally, public art is both 2- and 3- dimension objects such as sculptures, monuments, murals, paintings and street furniture, (Zheng 2017, Bak and Said 2014; Sharp et al. 2005; Selwood 1995) that are located in free access sites of public space including streets, square, plaza, subways, and parks, (Chang 2008; Hunting 2005; Kwon 2004) that attract people to involve actively or passively (Bak and Said 2014; Zebracki 2013; Wang 2009; Bach 2001).

Public Art is not just a piece of art; rather it has a deep relationship between the content and its audiences in term of enhancing opportunities, value economizing, qualities development and later on encourage a profound impact on a location (Zebracki 2013; Jasmi and Mohammad 2016; Knight 2011; Mustafa et al. 2009; Pycroft 2009). Public art is now a prominent part of our evolving culture and public history through giving uniqueness special meaning and importance to our cities (Zheng, 2017, McCarthy 2006; Hall and Smith 2005; Baker 1998) with more sites for public involvements and an interactive source for past, present, and future (Seixas 2013; Becker 2004; Norman, and Norman 2000) among different disciplines and thoughts. Any object or performance that can trigger something which is meaningful, something that can be a kind of self-realization, attachment or a confrontation may be included as public art (Patheja 2016; Landi 2012). Public art is part of the system by which a city gains a sense of definition which could show that what kind of city it is and what features of its history are to be preserved, (Hall \& Robertson 2001). Public art creates a community, and a community point of view (McCarthy 2006), the purpose of public art has now been progressed from just aesthetic appraisal to addressing more structural variations (Landi 2012; Hall \& Smith 2005; Philips 2003; Hein 1996). Ulrik Neumann stated in an interview with Hollywood patch that we usually identify cities or places that have their specific icons that have created their unique identity for which they are acknowledged. The Los Angeles city is swiftly recognized by Hollywood sign, the Eifel tower is the definition of Paris and San Francisco is known by the Golden Gate Bridge. All of these monuments or public art icons were created by very creative people who captured the spirit and atmosphere of their hometowns (Neumann 2014).

Scientists like (Chang 2008; Hunting 2005; Becker 2011), reported that Public Art is gaining momentum in developed countries. However, it is emerging and still debatable discipline in developing or low-income countries. Public art in the countries like Pakistan, whose ideology based on the Islam (97\%), has some controversy in the form of sculptures and paintings of living beings among different groups of societies depends on the extent of education, cultural and religious values of the society. According to one thought, Islam prohibits the depiction of animate being in the form of paintings, drawings, and sculpture to avoid the risk of idol worship. However, others argue that this depiction of animated beings is permissible if the art is not meant to be worshiped. No doubt this controversy may reduce the utilization of all possible options for Public Art in the country. However, public opinion will progress and change around permanent artworks as technological advancement happens in social norms, education, and politics (Trinier 2007). However, the personal tolerance level for art that depicts violence, nudity, or outrageous visuals are just because of individual response (Trinier 2007). The under-developed countries instead of rich cultural history either ignored or not fully explored their public art to the desired extent because of financial, cultural, ethnic or any other obstacles (Chang 2008) while the developed one has explored its potential using technological edges (Muhammad et al. 2012; Mustafa 2009). Public art could play a role in low-income countries where basic life needs are substandard, fewer job opportunities, fragile peace and security with lesser recreational activities (Chang 2008). In this study, we develop our understanding to evaluate the role of Public art historically, its know-how among different community groups, and their level of appreciative, predictions, cultural preferences, and issues concerning conflicts with the Islamic domain law and low-income countries particularly, Pakistan. 


\section{Material and Methods}

\subsection{Mode of Research}

The research study was a mixed- method approach in which both qualitative and quantitative sort of data was collected by involving site observations, interviews, group discussions, questionnaires, site photography, and some secondary data from relevant authorities (Creswell and Creswell 2017) during September 2015 to July 2016. To explore the history of public art in Pakistan a literature review was undertaken that compiled professional and academic knowledge from a spectrum of authors, including those authors considered significant in the study of, cultural planning and public art, history of Public Art, Islam and art, the awareness about Public art and related material about Public Art in Pakistan, etc.

\subsection{Site selection for study}

Preceding to the study three cities were considered best for data collection and filling out questionnaire accordingly. Out of the longitude map of Pakistan two historically ancient cities and one capital territory (Islamabad), where a composite representative of the whole country has now settled. Brief information on the individual cities is provided in their respective explanation. Among the cities, the study area was further divided into small spots according to the need and demand of questionnaire. The areas which were selected for data collection (surveys and questionnaire) were based on relevant information from the luxurious sites of cultural heritage areas, Public parks, living societies, motorways, University campuses, shopping Malls and Public streets. Three main cities of Pakistan were selected based on the information regarding geographic allocation, area, population, economic importance along with cultural and developmental perspectives. The selected cities include Lahore (East), Peshawar (west) and Islamabad (in the middle), which are geographically situated in a row (Figure 1). However, the former two cities are ancient, provincial capitals and historical in nature while the later one is the newly established

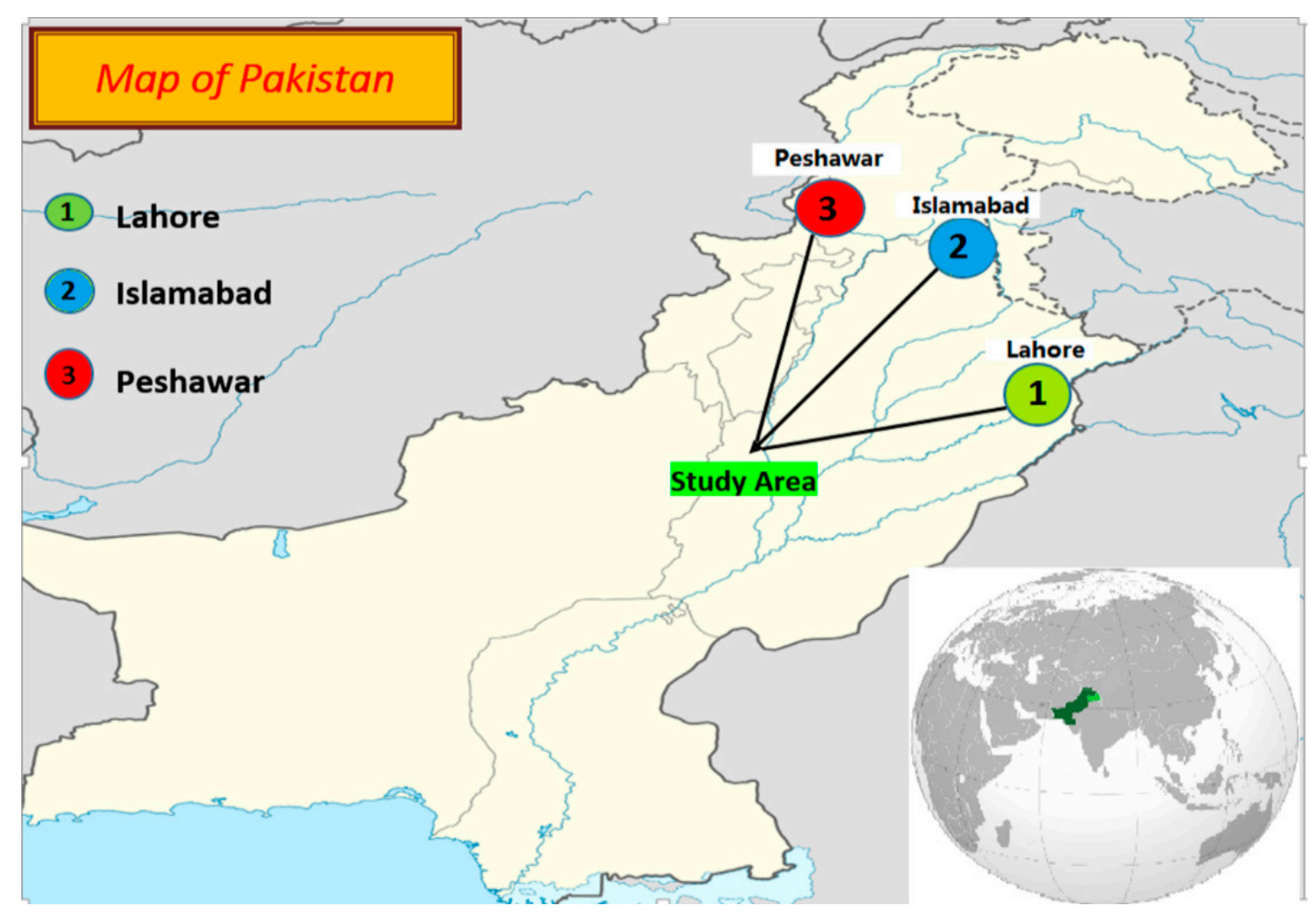

Figure 1 Sample Study Area in Map of Pakistan (Source: Google Maps edited by Author) 
City and the capital of Pakistan. Lahore, being the second largest city in the country with a population of 10.35 Million (2014 estimate) and culturally vibrant part of the Punjab province being a provincial capital, it has a combination of old and new well-protected infrastructure as compared to other cities. Similarly, Peshawar is located in the west of Pakistan, an ancient route of silk traders. Peshawar with a population around 3 million (2014 estimate), is located on the eastern border of Pakistan and adjacent to Afghanistan, has not protected well and millions of refugees were migrated and being settled during Afghan-Russia war. Most of the people belonged to Pashto on tribe and considered as conservative as compared with Lahore and Islamabad. Islamabad is the newly developed, the capital city of Pakistan with a population of 1.9 million (2014 estimate). Islamabad is well planned urbanized city of the country with several national parks. The majorities of the inhabitants are educated and belong to all part of the country. Most of the population belongs to middle and upper middle class. Both Liberal and religious mind people can be found here.

\subsection{Sample Size Selection}

A sample size of 450 respondents was selected with random sampling technique (Shah et al. 2017) with 200 from Lahore, 150 from Islamabad, and 100 from Peshawar. An utmost effort was made to approach as randomize population section of the sample as possible (Seixas 2013). The questionnaire was designed accordingly with research questions and objectives of the study correlated with types of public art in society, social and cultural preferences of public art in the local community, the understanding and misunderstanding of public art in a cultural and religious context, and the scope of public art in future perspectives. The number of participants who rejected taking the survey was additionally observed and were kept in the survey log for further tracking. Most of the surveys was collected directly by the facilitators by asking the participants questions and recording their answer with the help of a questionnaire and tape recorder where needed (Seixas 2013).

\subsection{Data analysis}

For statistical analysis, the data were collected, coded and imported into Microsoft Excel 2013. Labeling of each variable and value was performed, and missing data was also noted for elimination (Creswell and Creswell 2017). The qualitative and quantitative data were analyzed individually, while the survey data were analyzed using exploratory and confirmatory factor analysis with graphical representations of descriptive statistics.

\section{Results and Discussion}

Geographically the Urban landscape of Pakistan is composed of big and small cities and towns. Each of these cities and towns comprises of distinctive characteristics depending on its cultural and social background. The concept and application of modern public art in Pakistani cities and towns are new and has never been critically considered. Public art in Pakistan is gaining its importance, and people understand the concept of Public art gradually. In order to know well about the Public art in Pakistan, it is essential to identify the public art history in the country; the local people attitude towards public art and the cultural preferences of public art in cultural and religious context.

\subsection{History and Background of Public Art in Pakistan}

\subsubsection{Public Art History before Inception 1947:}

Pakistan has been placed as a center of ancient civilizations as revealed by the ruins of Sirkhup Sirsik, Juilian and Gandhara civilization and traced back up to 5000 BC (Dales 1964). The first phase of the history of sculptures and rock painting in Pakistan links back 2000 years old civilization of Mohenjo-Daro and Harappa, which were able to make images in carved stones and used bronze and other materials for the picture depiction (Naqvi 2010 p-232; Rao 1973). They made big and small statues of Buddha and other Animals from rocks and erected them in mountains and other different 
places of worship (Wright 2010). However, a part of the existence of such ancient heritage the region of Indo-Pak was being exposed to several civilizations, and some so many Conquerors destroyed these significant heritages just for the sack of nothing (Rao 1973). The second phase of the history of sculptures and art in the public places in the present day Pakistan date back to Moghul Empire (15261857). Catherine Asher wrote in her Book "The Architecture of Moghul India," that Akbar and Jahangir installed the marble sculptures of the defeated Rajas at the Gates of their palaces to serve as a reminder of the emperor's strength (Asher 1992 p-112). The third phase of the History and the modern Public Art foundation in the sub-continent ${ }^{1}$ was inaugurated by the British colonial government during 19th and 20th centuries (Naqvi 2010 p-233).

The British Raj sculptures were academic in British style of classical European sculptures and were meant to convey the fact of conquest and reform of art that went with the mission of civilizing the conquered. The earliest sculptures and other artworks of the British colonial time that are existed in Pakistan were the statues of British Royalty i.e. the sculptures of Queen Victoria (Fig 2a) and some different iconic personalities of that time like Alfred Woolner (Fig 2b) etc., which were placed mostly in Public places and were adequately commissioned by the colonial government since 1880s (Naqvi 2010 p-233). Besides the sculptures of the British rulers and royals, the British governors flaunted the iconic Clock towers in many cities of Pakistan with the British and Moghul style of architecture. These structures, later on, become the epicenters of the political activities and the iconography and landmark of the cities. The most prominent example of the Clock tower ${ }^{2}$ is the Clock tower of Faisalabad (Fig 2c). It is one of the oldest monuments of the British Raj built in 1903 by the British governor of Punjab Sir Charles Riwaz through a fundraising program. The structure of this clock tower looks like the Union Jack flag of the United Kingdom from a bird's eye view.

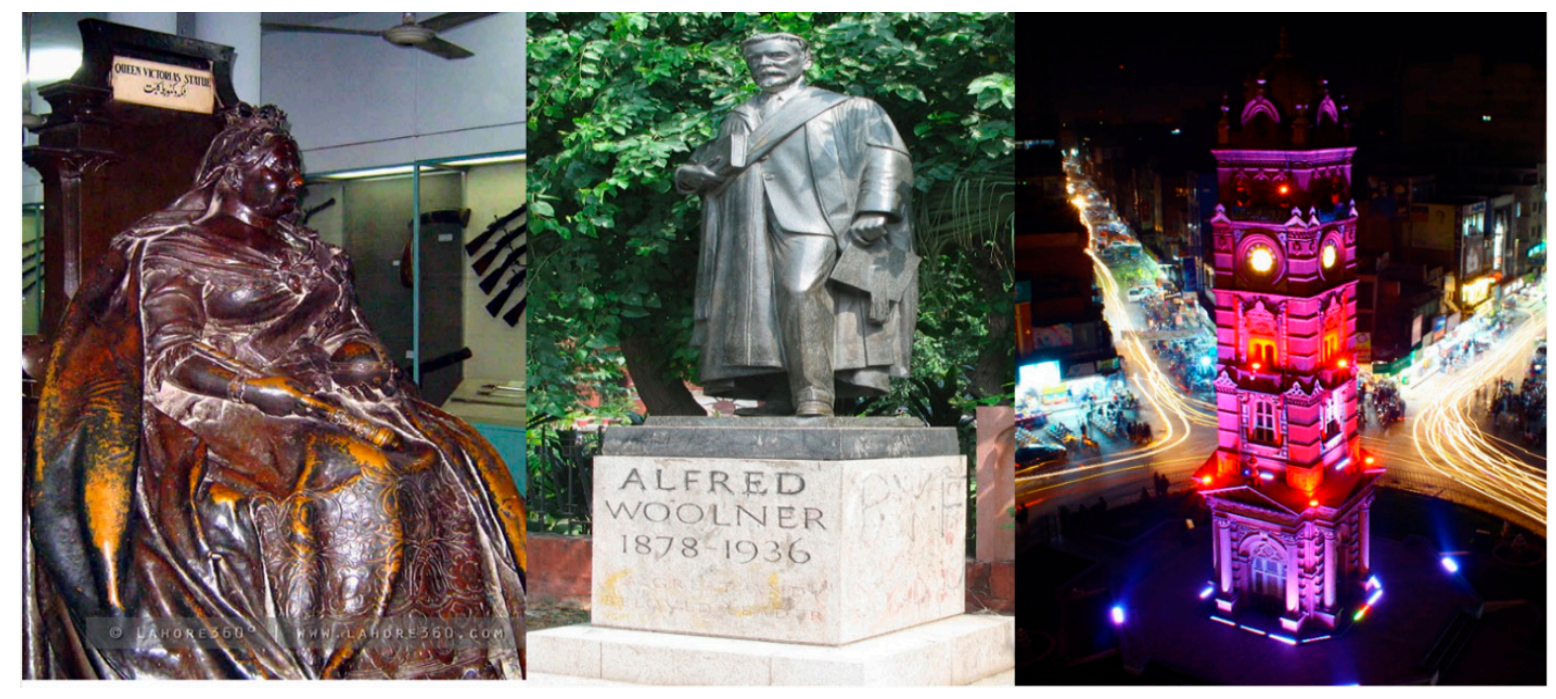

(a)

(b)

(c)

Figure 2 (a) The sculpture of Queen Victoria which were removed from the front of current Punjab assembly building in 1974 and placed in Lahore Museum (picture source Lahore360.com). (b) The sculpture of Alfred Woolner in front of Punjab University old campus, still existing in its original place since British colonial time (source: author field survey 2015-16). (c) The Monument of clock tower constructed in British Raj in 1904 in Faisalabad city that is still existing in good format. (source: Usman Nadeem; Wikipedia.org)

\footnotetext{
1 Sub-continent was a combined name used for Pakistan, India and Bangladesh before 1947 partition.

2 Clock towers are locally denoted as "Ghenta Ghar" which means "Hour House”.
} 


\subsubsection{Public Art History after 1947}

After independence of Pakistan in 1947, there were a lot of sculptures of British governors and royal families that were existed in Public-private places and were created in British time and these were slowly and gradually removed from the open spaces and government buildings and kept in the Museums by that time dictators Ayyub Khan and Zia-ul-Haq (Naqvi 2010 p-233). The Queen Victoria statue which was erected there in front of the present day Punjab assembly (at Chairing cross), was removed in the 1950s and kept in the safe custody of Lahore Museum, which is still existing in its original shape in the Museum. There were many more sculptures of the Royal couples in Lahore and Karachi that were taken down and stored in museums and open yards (Naqvi 2010 p-233). These were not done for Islam, but the president of Pakistan during 1950s Ayyub Khan was told by his bureaucrats to remove all these as it will be disrespect for King Faisal during his first visit to Pakistan in 1950s (Naqvi 2010 p-233). The Lahore Museum has over 300 works of the modern art collection, which should be preferably put in public places (Naqvi 2010 p-233). Only the bronze sculpture of Alfred Woolner (1878-1936) which was commissioned and installed by British colonial Government in front of old campus of Punjab University in Lahore was escaped from the eyes of bureaucrats during that time and is still existing there in its original place. Besides the British royal sculptures, the sculptures and figurative portraits of the prominent political leaders of the independence movement were commissioned and constructed in the free access locations including public squares, public plazas, national libraries, university campuses, and other government and private sort of buildings (Fig 3). These sculptures of the high profile political figures have significant historical and cultural influence and educating a broad number of a young generation about the role and political will of the leaders of the independence movement.

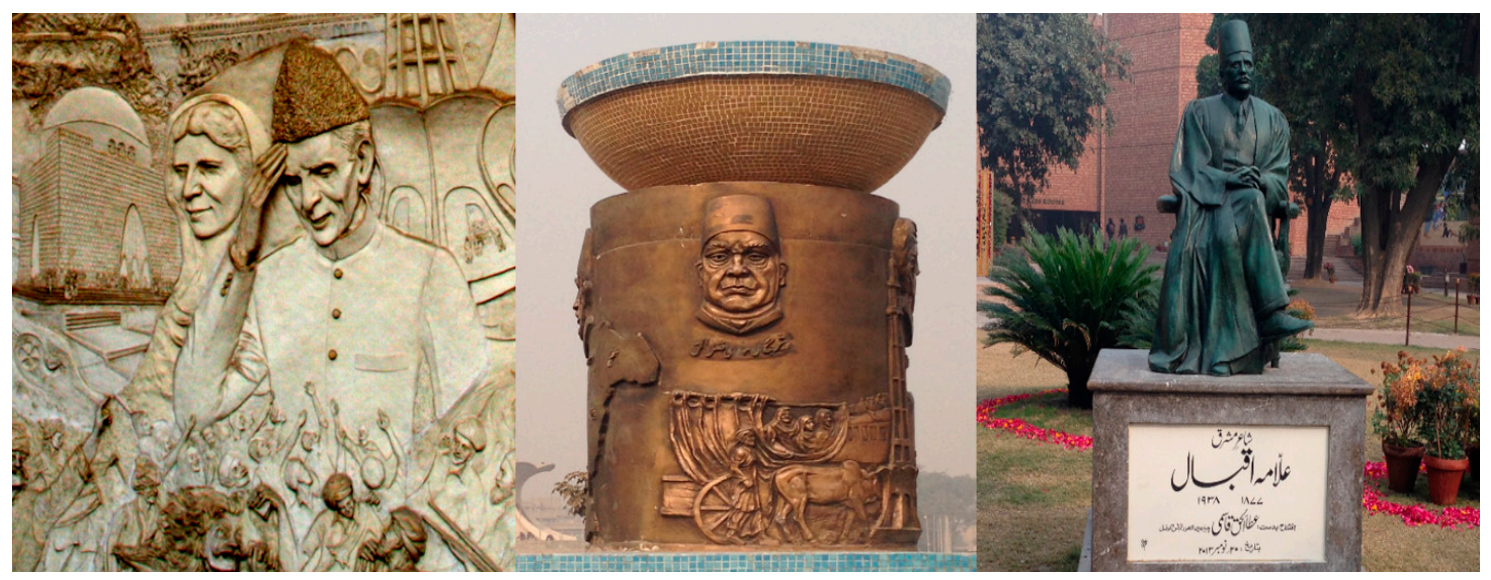

(a)

(b)

(c)

Figure 3 (a) Portrait of Muhammad Ali Jinnah the Founder of Pakistan and his sister at Pakistan Monument Islamabad (b) Portrait of Molvi Fazal Haq (one of the Prominent Leader of Pakistan Independent movement) located at greater Iqbal Park Lahore (c) A sculpture of Allama Muhammad Iqbal the National poet of Pakistan and an Imaginary founder of Pakistan located at Alhamra Hall Lahore. (Source: Author field Survey 2015-16, edited by Author).

After these earliest power manifestations, the very first works that had a convinced art and public appeal came up in the 1960s as great monumental tower locally called "Minar-e-Pakistan" (Fig 4a). This is a public monument located in Greater Iqbal Park Lahore, one of the largest urban parks in Pakistan. This impressive and eye-catching tower was constructed on the site with a unique historical background as on 23rd March 1940 there was a resolution passed for a separate country (Pakistan) by all India Muslim League at the British colonial time. The construction of this public art monument started on 23rd March 1962 and completed on 22nd March 1968. The height of the tower is 62 meters with a diameter of 10 meters. This monument is considering as the National tower of Pakistan which was constructed with a Public fund of 0.7 million Pakistani Rupees (PKR) (Jamal 
2002). This was the first ever public funded Public Art project in the country since independence. The second prominent example of the public funded public art project is the Bab-e-Khyber monument near Pak-Afghan border in Peshawar (Figure 4b). This monumental gateway was constructed in 1964 with a fundraising program by the local government of Peshawar. This type of Public art depict the history and culture of the area which have witnessed to countless invaders and great warriors that had entered the rich and fertile lands of the subcontinent. Islamic Summit Minar is another prominent example of Public art located at Chairing Cross in front of the Punjab Assembly Hall Lahore. This monument was constructed in 1974 to commemorate the Islamic summit conference held in Lahore. It is 155 feet high, composed of an obelisk-shaped structure and was designed in the spirit of Islamic unity. Similar installations of outdoor artworks were occasionally continued at different locations of the country by private firms and estate developers in the 1970s, 1980s, and 1990s. Until that time, the commissioned and non-commissioned artworks installed by the government and private enterprises were not exactly considered as "public art" because their representation was mostly decorative and their status was very little consideration as art in public places. A significant change took place in the field of public art in the country as the setting up of Pakistan Monument that was constructed in 2007 by Musharraf Government in Islamabad which is an adequately commissioned public artwork by the federal government of Pakistan (Fig 4c). The Pakistan Monument is considered as the national monument which portrays the culture and history of four provinces and three territories of the country. Arif Masood's a well-known architect of Pakistan was selected for the final design after a competition amongst many prominent architects and artists. The budding flower shape of the monument denotes the progress and prosperity of Pakistan as a fast developing country in the world. The four main and big petals of the monument symbolize the four provinces (Baluchistan, Punjab, Khyber-Pakhtunkhwa, and Sind), while the smaller three petals embody the three territories (Azad Kashmir, Gilgit-Baltistan and the Federally Administered Tribal Areas FATA). This Monument was commissioned and constructed for the purpose to reflect the culture and social norms of the country as one unit. The design work depicts the historical movement of Pakistan independence, dedicated to those who sacrificed themselves for future generations.

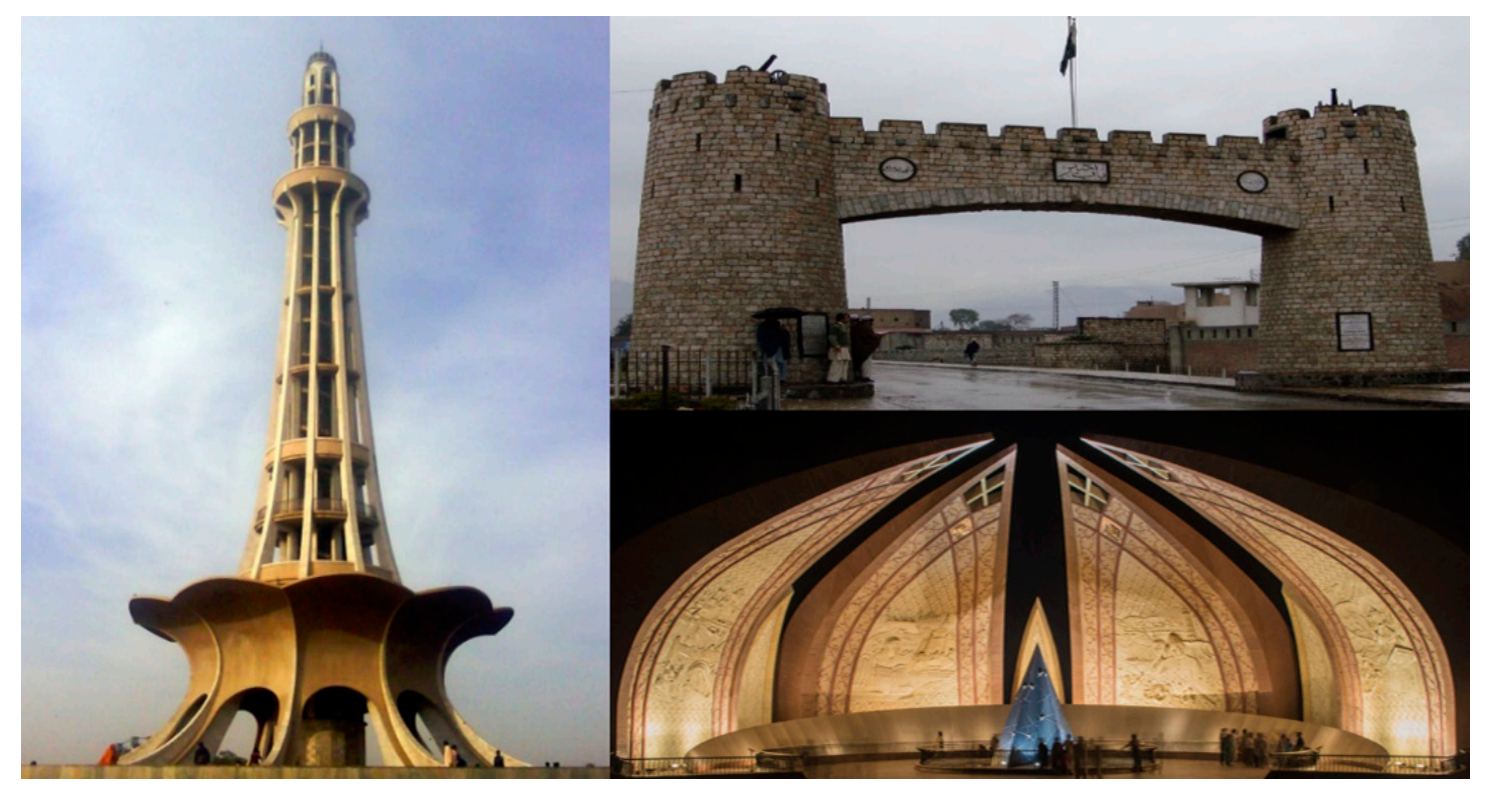

(a)

(b)

(c)

Figure 4 (a) Minar-e-Pakistan the monumental tower of Pakistan, the first commissioned Public art installation in the country constructed in 1968. (b) The Gate of Khyber locally call Bab-e-Khyber constructed in 1964 located in Peshawar on the Khyber Pass one of the ancient Silk rout (c) The Pakistan Monument constructed in 2007 located in the capital city Islamabad (source: author field survey 2015) 
The term "public art" got into usage and replaced earlier titles like sculptures, murals, monuments and outdoor arts when Malik Riaz Husain a Pakistani real estate tycoon commissioned and constructed tremendous amount of public art in Bahria Towns since 2000. Bahria Town is a group of residential privately owned real-estate development projects which own, develops and manages properties across Pakistan. The main attraction of Bahria town is the Public Art installations which makes it unique and most attractive in comparison with housing societies of Pakistan. There are considerable amount of public art structures located in each and every corner of Bahria towns both in Islamabad and Lahore (Fig 5). In Bahria town, one can found all sorts of public art such as murals, monuments, historical sculptures, street art with special artistic appeals, and modern and ancient types of artworks, which are the unique characteristics of these urban landscape.

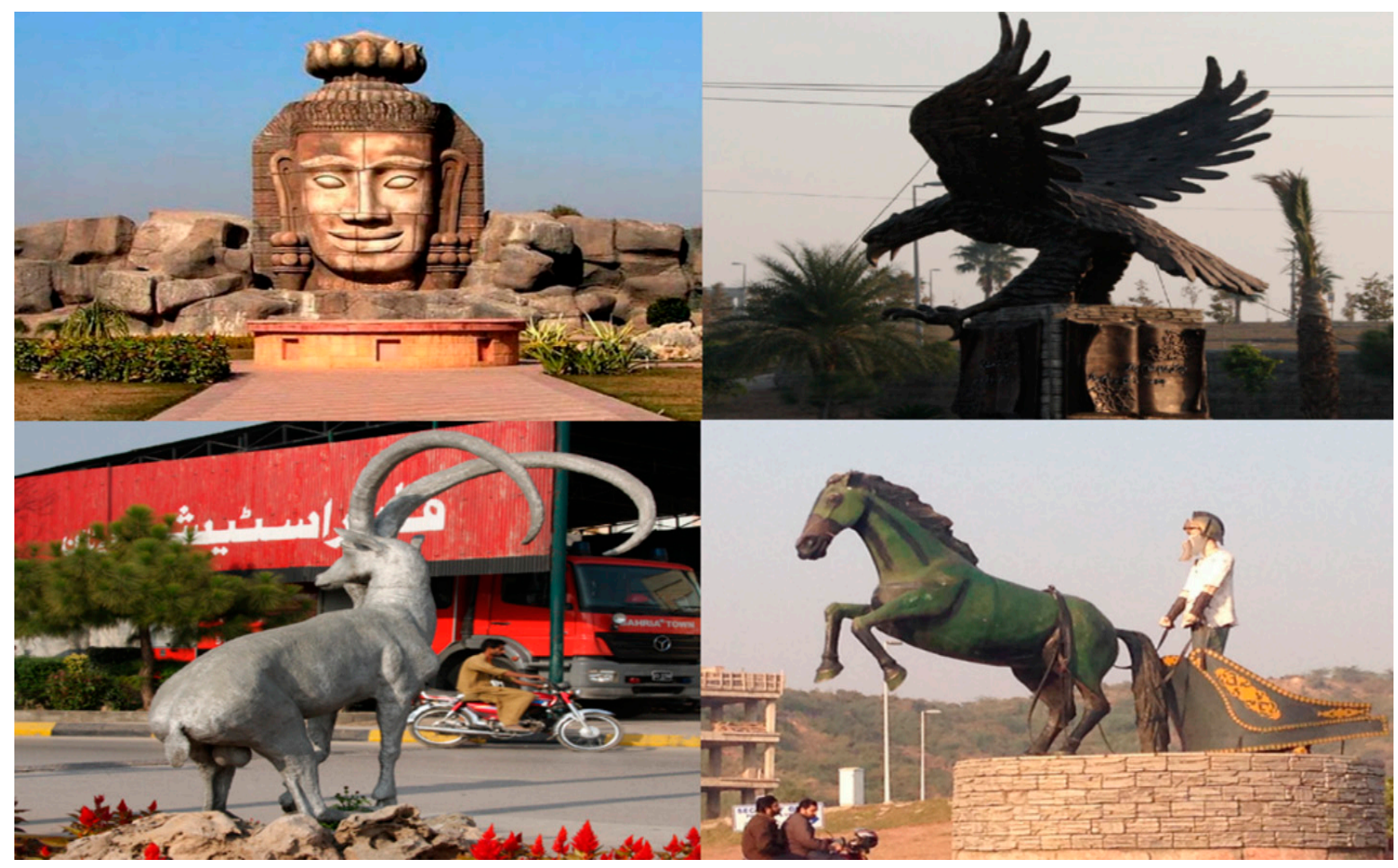

Figure 5 represents different types of Public art and sculptures in Bahria Town Islamabad and Lahore. (Source: Author field Survey 2015-16

There are small and big public art installations in different cities of Pakistan to varying localities like public parks, open squares, road junctions, in front of public buildings, and metro stations, etc. These public art pieces anonymously constructed and designed by unknown artists where artist's information are not available on the site as well in literature. There are some sculptures installed in F-9 Park of Islamabad, and these were probably introduced during 2001 to 2007 when the park was commissioned to a Japanese Company JICA for its reconstruction and renovation purposes. The Bacha Khan memorials in Peshawar, Mardan, Quetta, and Karachi are also some of the famous sculptures showing the legacy of Late Abdul Ghaffar Khan one of the old Congress leader and prominent figure before partitioning of Indo-Pak. Most of this public art were installed in open squares and road junctions at different times by governments and private firms since the 1990s. The contemporary artworks in Kalma Chowk, Lahore (Fig, 6a) and the Peace Chowk (peace square) in Peshawar (Fig, 6b) are also some good examples of the public art which is giving these localities a sense of identity. The recent installation of public art "city within a city" (Fig, 6c) in Istanbul Chowk Lahore completed in 2015 got more fame on social media and TV shows as one of the noticeable and modern public art installation in the country. This work was efficiently commissioned by Lahore Biennial and Commissioner of Lahore which was assigned to Atif Khan, a lecturer at the National College of Arts after a proposal evaluation by famous artists and architects of Lahore. 


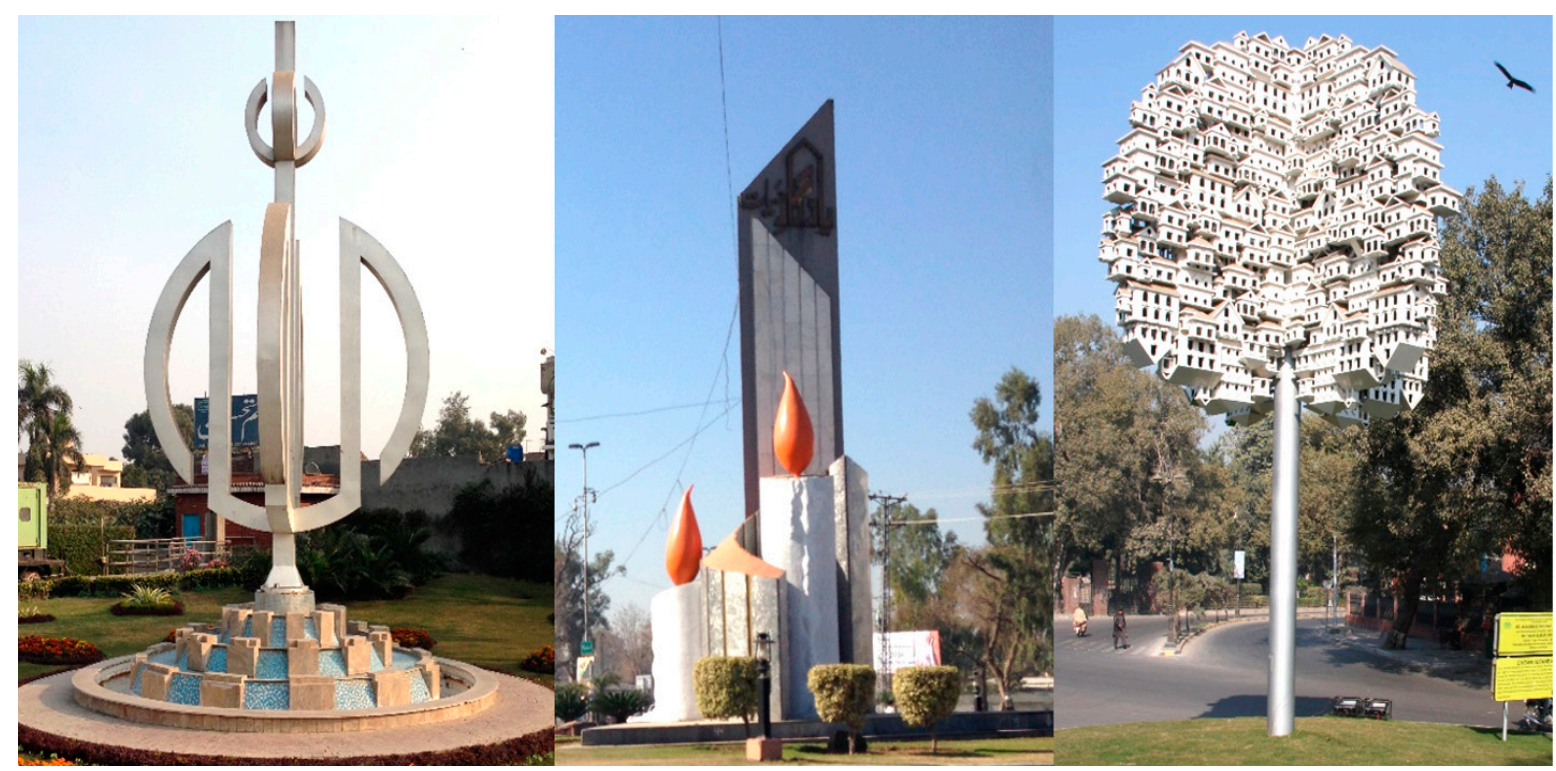

(a)

(b)

(c)

Figure 6 (a) A sculpture in Kalma Chowk Lahore representing the Name of Allah (GOD) in Arabic Language. (b) A public art installations of candles under the theme "we want peace" in peace square Peshawar. (c) A public art installation called "city with in a city" in chowk Istanbul Lahore representing the history and culture of the site.

\subsection{The Logic behind Public Art in Pakistan}

Pakistan has some unique feature as compared to rest of the world has a considerable difference in its elevation, crop choice, topography and climate besides all these the public art created in Pakistan has also exhibited uniqueness in its creation. There is a vast variety of Public art existing in Pakistan. These include Historical Monuments, National monuments, Murals with historical and cultural backgrounds, Sculptures of living and non-living beings, Modern sculptures, Historical sculptures, Public art with particular themes, Public art with social and cultural context and Public art with the religious association. Most of these Public art installations are made of concrete materials followed by different kinds of plasters and steel. Sculptures made of stone carving also existing in the country. Consequently, some of the pieces of arts which have been installed in different societies of Pakistan are abandoned and ignored by the people. In fact, a creative public artwork should resonate with the site and surroundings, should create opportunity and welcome people to engage with it. The public art field in Pakistan has many constraints and limitation in terms of cultural and religious norms followed by economic barriers. The political governments have given less importance towards the art in public domain which resulted in lack of awareness about art in local communities. Whenever somebody talks about 'public art' in Pakistan one wants to look for something possibly it's meaning in their own perspective. Like every other trend, borrowed and introduced from outside (mainly the West), the idea of modern public art is also gaining popularity in our art world. However, besides all these limitations there are some calligraphic work and the culturally supportive work that have been keenly done in the religious buildings, government-owned areas, military relevant art pieces using as symbols for the traditional nature of the people and the majority of them oriented towards public art in the recent years. In an interview with an artist and lecturer at the National College of Arts it was said that "If the field of public art is to grow up and to be mature in the country, it will need to define better practices of public art field with the same standards as practiced in developed countries... with the full cooperation of government and public support... which could boost up the public art field in the country." 


\subsection{Cultural preferences of Public art in Pakistan}

Pakistan is a country with diverse culture and identities. It consists of four provinces and some autonomous regions which have their unique culture and local identity and differ from each other to some extent. The main thing which combines all these cultures and brings them together with each other is religion and religious activities which are shared and similar throughout the country. The local culture and Islamic thoughts have a significant influence on the events and structures of public art in the local societies. Human sculptures and Nudity in sculptures are not considering good in Pakistani communities. Therefore there are very less human statues existing with no nudity and no female sculpture in public places. Most of the Human sculptures which are present is either some ancient sculptures from British colonial time or of those leaders or activists who took part in Pakistan Independent movement dominantly of the founder of Pakistan Quaid-e-Azam Muhammad Ali Jinnah and the national poet of Pakistan Allama Dr. Muhammad Iqbal. During the field survey, we asked the local community of Lahore, Islamabad, and Peshawar about the cultural preferences regarding public art type that has been widely preferred and acknowledged in their surroundings and neighborhoods. A sample size of 450 respondents was given the option to choose more than one of the types of public art they would prefer in their regions and was supposed to be connected with the local culture and the history of the area.

Figure 7 shows the results of our survey revealing that majority of the respondents $(85 \%)$ preferred to see and appreciate the historical and cultural monuments. They were in a significant association of the cultural and historical backgrounds of the artworks such as Minar-e-Pakistan, Pakistan Monument, Bab-e-Khyber, etc. which have profoundly depicted in the hearts of the local inhabitants of Pakistan. In this case, Lahore stood number first with $(90 \%)$ of the respondents have a positive attitude towards the cultural and historical monuments followed by Islamabad ( $84 \%$ ) and then Peshawar (80\%). In contrast, fewer respondents (26\%) preferred the Sculptures of living beings to be freely located in the local environment while the remaining were in a state of disagreement due to the sole reason that Islam has prohibited the depiction of animated being in the form of paintings and sculptures. The others argued that these sculptures and portraits of the human being and other animals can be permissible if the art is not meant to be worshiped, most of them clarified it should be the sculptures or statues of the leadership and martyrs who have prominently sacrificed for the independence and integrity of the country. Majority of these respondents belonged to Islamabad $(39 \%)$, where the society is more liberal and educated as compared to Lahore and Peshawar which has more conservative people.

The case is different with the sculptures of non-living things, where $(68 \%)$ of the total respondents was in favor of these sculptures with various modern and architectural shapes. Several respondents argued that these types of structures can be used with some particular themes to broadly educate a number of audience from societal and intellectual issues. $(64 \%)$ of the respondents were interested in street art and street furniture with distinctive design and thematic background that can swiftly attract the visitors and pedestrians to engage with it actively or passively. (57\%) of the respondents showed their interest in graffiti and murals which could be used to present the culture and history of the society and locality and could also address the social issues with particular images or signs and specific thematic display. The second largest group $(80 \%)$ of the respondents agreed to appreciate the Islamic contemporary art in the public domain, while some of the contenders did not agree to see the public art based on Islamic theme in open spaces as they argued that some of the Islamic art contains the calligraphy of the verses of Holy Quran and Hadith if presented in the open squares and other public places would be disrespected by someone which is not allowed in the religious and cultural domain. These survey results demonstrate that majority of the respondents were interested in cultural and historical monuments while very less were concerned in sculptures of animated beings. These results reveal the preferences of the local community in a tight contest with cultural norms and religious ethics of the local societies of Pakistan. Which could be further correlated with the policies and development of public art in the country. 


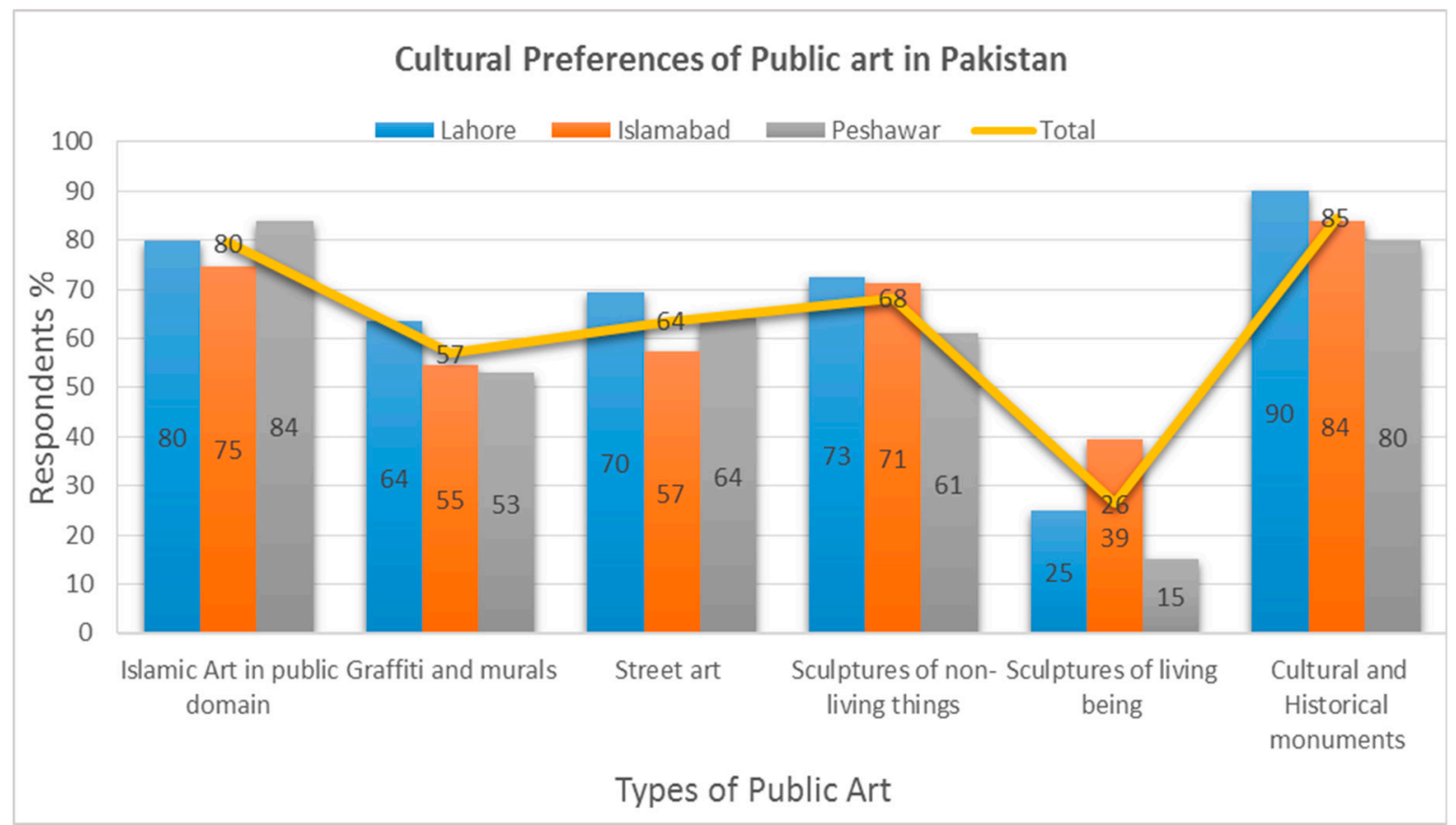

Figure 7 illustrations the attitude of the survey respondents towards the type of public art in the study area of Pakistan.

The available information of each city when individually assessed showed that variation exists among the communities and their choices. Lahore is the center of cultural heritage and providing opportunities to the communities regarding public art more frequently having a good response regarding public art and relevant ideas. Similarly, the capital territory Islamabad being a wellplanned and among the top beautiful cities of the world having numerous parks and public art pieces connected with its urban landscape. The worst city Peshawar has limited facilities while the public has less access to approach such art places like Peshawar fort. Additionally, Peshawar city has been exposed to millions of Afghan refugees and was severely suffered during the Afghan-US war against terrorism. But in the recent past, the newly elected government have focused on public art, and some art pieces are being installed in public places.

\section{Conclusion and recommendations}

It is evident from the detailed provided in the findings section of this study, where Pakistan heritage is rich enough in ancient and modern public art. Though the cultural variation and spiritual impulsion may restrict, it's grooming yet the potential for the different ideology cater so many other options for public art such as the historical background of Pakistan, different languages and different regions comparisons and color of lifestyle. Former sections of this study highlighted the detailed information in this regard.

The issues concerning public art created during the British era were either protected in government offices, cultural heritage, Art colleges or museum instead of public places. On the other hand, public art pieces that reflect Pakistan independence, people hospitality, agricultural and other landscapes have been still prominent. Art and public art were not the cups of tea of the government since the day of independence. However, government decision may not be wrong because of the crises faced by the country especially during the war on terrorism in the near past. As public art gaining momentum in advanced countries and considered as an authentic source of income, people interaction, communication, and development enhancement. During this digital life, public art is the particular recreational activity, and people want to save their sweet memories which have been gradually reduced due to speedy lifestyle.

Interestingly, the core research questions being addressed was, what is the history of public art in Pakistan, what types of public art existing in the community, what are the local people 
understanding and perceptions about public art, what sort of public art are acceptable and being welcomed and which kinds are not considering good in religious and cultural context. None of the citizens have shown any aggression regarding the public art. However, variation exists among these communities, their education, and priorities with respect to art pieces. Yet, the statues and sculptures were disliked by the individual, but on the eve of their installation in any public place, no rigid behavior has been seen in the country such as Bacha Khan Sculpture at Peshawar city. This has been achieved through integrated approach includes; site observations, field survey, interaction and interviews with local community and cooperation from local authorities and local artists of the study area. The fundamental research objective of this study was to explain public art field in the local context, to highlight its importance in the local community and to establish a background of the Pakistani public art at regional and global level. By researching the aims, process, and objectives, the outcome of this study was not only constructive instead appreciated. The history of public art in Pakistan has been explained from pre-independence to post-independence with examples and symbolic representations where needed.

The lack of awareness about public art in Pakistani communities is due to some factors involving; 1. Less importance has been given to the Public art and related fields by government authorities, 2. Lack of fund availability, 3. Cultural and religious miss-understanding of artworks by local communities, 4. Lack of art schools and colleges in the country, 5. No proper organizations on city or province level which could deal with the public art and its commission and installation in their local areas. All these factors are affecting public art and its practices in the country.

Last but not the least, if a little focus is given to this creative work, it will change the status of the people with prosperity. However, to avoid controversy among the public first step art pieces should concern to the art pieces that reflect the norms of the local culture, the ethics of local society, the bravery of the local people, peace loving nature of Muslims, natural and cultural landscape models. Once getting start people will orient and motivate PA pieces and thereafter such art help to boost their awareness, importance, and role towards public prosperity. This research will fill the gap in studies on public art and its role in Pakistani context. It will also fill the gap in the literature on Pakistan urban landscape, in which, Public Art has not yet been fully explored.

\section{Acknowledgments}

This study is part of a Ph.D. research at the College of Horticulture $(\mathrm{COH})$, Department of Ornamental plants and landscape architecture, China Agricultural University, Beijing, China. This research is made possible with the support of Chinese Scholarship Council (CSC). The authors are obliged to the College of Horticulture ( $\mathrm{COH}$ ), China Agricultural University, as well as National College of Arts (NCA) Lahore, Capital Development authority (CDA) Islamabad and Peshawar developing authority (PDA) and local governments' representatives for their effective support in organizing and conducting interviews. Further, we would like to thank our survey team members Muhammad Atif Khan, Muhammad Imtiaz, Abbas Iqbal, Muhammad Irfan, and Shams-uz-Zaman in conducting interviews and filling out the questionnaires during September 2015 to February, 2016.

\section{Author Contributions}

Each author contributed to the research in terms of conception, research design, cross-checking data analysis and co-writing the paper. SAS was primarily responsible for data collection, analysis and writing of the paper. All the authors read and approved the final manuscript.

\section{Conflicts of Interest:}

All of the authors have no conflict of interest.

\section{Funding:}

This research did not receive any specific grant from funding agencies in the public, commercial, or not-for-profit sectors. 


\section{References}

Asher, Catherine Blanshard, and Catherine Ella Blanshard Asher. 1992. Architecture of Mughal India. Vol. 4: Cambridge University Press.

Bach, Penny Balkin. 2001. New Land Marks: public art, community, and the meaning of place: Grayson Pub.

Bak, Yeoa Lee, and Ismail Saidb. "Influence of Public Art on People Attachment towards Space in Heritage City, Georgetown, Penang."

Baker, A. 1998. Public art in critical perspective. Paper read at American Anthropological Association Meetings, December.

Becker, Jack. 2004. Public art: An essential component of creating communities: Americans for the Arts.

Becker, J. 2011. "The Gospel of Public Art." Public Art Review no. 22 (2):11.

Chang, TC. 2008. "Art and soul: Powerful and powerless art in Singapore." Environment and planning A no. 40 (8):1921-1943.

Creswell, John W, and J David Creswell. 2017. Research design: Qualitative, quantitative, and mixed methods approaches: Sage publications.

Dales, George F. 1964. "The mythical massacre at Mohenjo-daro." Expedition no. 6 (3):36.

Hall, Tim, and S Smith. 2005. "Public art in the city: Meanings, values, attitudes and roles." Interventions. Advances in art and urban futures:175-179.

Hall, Tim, and Iain Robertson. 2001. "Public art and urban regeneration: advocacy, claims and critical debates."

Hein, Hilde. 1996. "What is public art?: Time, place, and meaning." The Journal of Aesthetics and Art Criticism no. 54 (1):1-7.

Hunting, Daniel. 2005. "Public art policy: Examining an emerging discipline." Perspectives in Public Affairs no. 2.

Jamal, Amna. 2002. The Pakistan Day memorial. Dawn News Pakistan, Published, 23 March 2002. Retrieved 12 February 2015. Available at https:/en.wikipedia.org/wiki/Minar-ePakistan\#cite_ref-amna_3-0 
Jasmi, Muhammad Falihin, and Nik Hanita Nik Mohamad. 2016. "Roles of Public Art in Malaysian Urban Landscape towards Improving Quality of Life: Between Aesthetic and Functional Value." Procedia-Social and Behavioral Sciences no. 222:872-880.

Knight, Cher Krause. 2011. Public art: theory, practice and populism: John Wiley \& Sons.

Kristy Trinier. 2007. Context and Controversy: the Incendiary Potential of Public Art. Edmonton Arts Council. Available at http://publicart.edmontonarts.ca/

Kwon, Miwon. 2004. One place after another: Site-specific art and locational identity: MIT press.

Landi, Pamela Jo. 2012. "Public Art-Purpose and Benefits: Exploring Strategy in the New England City of Pittsfield, Ma."

McCarthy, John. 2006. "Regeneration of cultural quarters: public art for place image or place identity?" Journal of Urban Design no. 11 (2):243-262.

Mohd Fabian, H, MT Osman, and B Mohd Nasir. 2012. "Towards Integrating Public Art in Malaysian Urban Landscape." Pertanika Journal of Social Sciences \& Humanities no. 20 (2).

Mustafa, Muhizam. 2009. "Public Art in the Federal Territory of Putrajaya: Questions of Value and Role." Wacana Seni Journal of Arts Discourse no. 8.

Naqvi, Akbar (2010), Image and identity: Fifty years of painting and sculpture in Pakistan, Oxford university press, Second edition, ISBN 978-0-19-547172-4 p. 232-259.

Norman, EH, and JM Norman. 2000. "Community operational research issues and public art practice: the art director system." Journal of the Operational Research Society:510-517.

Omar, Siti Syamimi, Siti Rasidah Md Sakip, and Norizan Mt Akhir. 2016. "Bringing the New to the Old: Urban Regeneration through Public Arts." Procedia-Social and Behavioral Sciences no. 234:515-524.

Patheja, Jasmine. 2016. An interview with Jack Becker published in Public art review on July 15, 2016.

Phillips, Patricia C. 2003. "Public art: A renewable resource." Urban futures: Critical commentaries on shaping the city:122-133.

Pycroft, Christopher. 2009. Inspiring creative approaches for town centers Benefits, advocacy and commissioning guidance. Page. 7. Available at http://www.publicartonline.org.uk/

Rao, Shikaripur Ranganatha. 1973. Lothal and the Indus civilization: New York: Asia Publishing House. 
Roberts, Marion. 1995. "For Art's Sake: Public art, planning policies and the benefits for commercial property." Planning Practice \& Research no. 10 (2):189-198.

Seixas, Naomi. 2013. A survey conducted on "Does Art Matter: Assessing the social value of Public Art in New York City's Transit System."

Selwood, Sara. 1995. The benefits of public art: The polemics of permanent art in public places. Vol. 770: Policy Studies Institute London.

Shah, Ashfaq Ahmad, Jingzhong Ye, Muhammad Abid, and Raza Ullah. 2017. "Determinants of flood risk mitigation strategies at household level: a case of Khyber Pakhtunkhwa (KP) province, Pakistan." Natural Hazards:1-16.

Sharp, Joanne, Venda Pollock, and Ronan Paddison. 2005. "Just art for a just city: public art and social inclusion in urban regeneration." Urban Studies no. 42 (5-6):1001-1023.

Neumann, Ulrik. 2014 An Open Post on why public ART is so important! Thoughts on why we underestimate the importance of public ART - published October 19, 2014, 11:21 pm ET. Available at https://patch.com/users/ulrik-neumann

Wang, Po-Ching. 2009. A Public Perspective on Public Art's Characteristics and Its Contributions to the Urban Fabric: A Case Study in Taipei City, Taiwan, Pennsylvania State University.

Wetenhall, John. 1993. "A Brief History of Percent-for-Art in America." Public Art Review no. 9.

Wright, Rita P. 2010. The ancient Indus: urbanism, economy, and society: Cambridge University Press.

Zebracki, Martin. 2013. "Beyond public artopia: public art as perceived by its publics." GeoJournal no. 78 (2):303-317.

Zheng, Jane. 2017. "Contextualizing public art production in China: The urban sculpture planning system in Shanghai." Geoforum no. 82:89-101. 